\title{
The Positive Role of Small Businesses in Scaling down the Shadow Economy Phenomenon and Its Negative Impact on the Private Sector and the National Economy: An Exploratory Study in the Province of Jeddah
}

\author{
Nayef Al-Ghamri ${ }^{1}$ \\ ${ }^{1}$ Department of Human Resources, Faculty of Economics and Administration, King Abdulaziz University, Jeddah, \\ Saudi Arabia \\ Correspondence: Dr. Nayef Al-Ghamri, Department of Human Resources, Faculty of Economics and Administration, \\ King Abdulaziz University, Jeddah, Saudi Arabia. Tel: 966-56-136-4017.
}

Received: March 21, 2016

Accepted: April 5, 2016

Online Published: November 16, 2017

doi:10.5430/rwe.v8n2p25

URL: https://doi.org/10.5430/rwe.v8n2p25

\begin{abstract}
The shadow economy phenomenon is widespread and has detrimental effects on the business sector and the national economy. The philosophy of shadow economy involves complex and overlapping perceptions related to conducting legal as well as illegal businesses. The shadow economy is not a new concept but one that has existed since the first known system of tax levies, and that has spread throughout the developed and developing countries of the world in equal measure. Shadow economy is often associated with illegally-gained proceeds (dirty money) originating from unethical and unlawful small businesses such as sexual slavery/exploitation and the drug trade. It is considered as detrimental to national economies and is rapidly spreading globally in the modern era. Weak, poorly designed or implemented controls by some countries, in addition to administrative corruption, have significantly contributed to the emergence and spread of shadow economies. The expanding scale and growth of shadow economies comes in spite of international efforts to enforce laws and regulations on this issue. The phenomenon has continued to spread despite global efforts to create and increase public awareness on the issue and notwithstanding dissemination of information to increase knowledge of the risks arising from this phenomenon and its economic impacts. Based on the severe threats shadow economies constitute and their effects on economic and social order, the subject has been recently included in the syllabus and course design of international as well as Arab universities. Legitimate and illegitimate business owners and individuals engage in shadow economies, whereby they attempt to evade payment of state taxes by benefiting from widely pervasive administrative corruption.
\end{abstract}

Keywords: shadow economy, small businesses, globalization, fraudulent businesses

\section{Introduction}

The current century has witnessed numerous developments in terms of globalization, information technology and knowledge. Nowadays, we are living in the knowledge-driven era where new concepts are paramount, including the digital economy and the Internet. Simultaneous with the prominent role of technology in modern life, globalization has also played a similar role in the transfer of knowledge and cultures. As industrialized countries have benefited from industrialization, they have similarly benefited from knowledge and technology and have thus secured pre-eminence and positions of world leadership and power. Globalization has contributed to eliminating economic and cultural barriers between nations and technology has similarly eliminated disparities of time and location. Subsequent to the advent of globalization and technology, the world has also witnessed the emergence of the 'shadow economy'. Gutmann (1977) was the first to draw the world's attention to this phenomenon. He focused on the effects of shadow economy on gross domestic product (GDP) and stressed that shadow economies are growing in some countries at a faster pace than formal economic performance. Moreover, he highlighted the undesirable economic consequences of informal economic activities. Amongst the most common, rampant and widely spread means of shadow economy activities in Saudi Arabia is when foreigners conduct business under the name of Saudi nationals. By so doing, people involved in such businesses do not abide by any constitutional or commercial laws leading to situations where legitimate businesses commit illegal acts, while registered businesses' operations are 
interwoven with operational aspects of non-registered businesses. Shadow economy workers' external remittances are intermingled with billions of dollars of legitimate registered workers' and foreign laborers' salary remittances in all classes of position and employment fields and vary tremendously in financial amounts remitted. These encompass plumbing, the general service range, medicine, fraudulent businesses, money laundering and currency smuggling via modern technology. According to Jumaah (2014), the size of shadow economy reached 330 billion riyals (\$90 billion) in 2012. A big portion of the shadow economy is concentrated in gold and jewelry trade and commercial concealment as it reached 270 billion riyals ( $\$ 71$ billion) in the same year in 2012 . Then, its size rose rapidly to reach 549 billion riyals ( $\$ 146$ billion) in 2014 as reported by Thunayyan (2014). The scope of the shadow economy covers a diversified and fertile field. It is considered the easiest way to build rapid wealth for citizens and residents who conceal their work and accounts, and seek to evade government supervision. Shadow economy operatives are basically illegal operators who perform a series of violations as follows: violations against state laws and its legal obligations (through non-registered and non-licensed business activities); violations against the state financial obligations (through evasion of taxes and avoidance of fees payment); violations against state administrative obligations (total lack of commitment to recruit the country's own citizens); violations of state security obligations (by trading in drugs, weapons, theft, human trafficking and sexual slavery); all of which are conducted 'under the radar', undetected by surveillance of the legitimate authorities. This study attempts to identify shadow economy operations and its relation with small businesses in order to form optimal strategies that can be employed to defeat it.

\subsection{Importance of the Study}

The importance of this study lies in its ability to analyze theoretical issues related to the shadow economy. The study considers and investigates the shadow economy concept, addresses the causes of its growth and identifies the best available means to combat it in Saudi Arabia. The study also clearly depicts the negative economic and social consequences that stem from the existence and operations of the shadow economy.

\subsection{Research Problem}

Hidden economies are very substantial compared to national incomes in some countries, where they may extend to approximately $50 \%$ of the national income. Large sums are gained by hidden economy operatives as a result of tax evasion and illegal acts such as drug and sexual slavery/exploitation. Organized crime, in particular, is considered one illegal means of illicit economy operations managed by personnel specialized in circumventing state regulations. Organized crime operatives adapt all modern technical means and human resources to achieve their goals by controlling the official authorities' employees' by means of illegal and unethical practices such as bribes and other financial inducements. Taking all this into account, the researcher tackles the research problem in an attempt to identify the concept of the shadow economy and its negative effects on the economy and society.

\subsection{Objectives of the Study}

This research paper's overriding aim is to shed light on the factors that encourage the increase of shadow economy activities. In particular, the following specific goals are addressed:

- Explore the shadow economy concept.

- Show the means by which shadow economy activities are exercised.

- Investigate the shadow economy characteristics.

- Analyze specific activities that have subsequently proven to be the main sources of shadow economy funds.

- Extend the analysis to other negative shadow economy effects on levels of economic, social and health development.

\subsection{The Research Hypotheses}

1- A correlation exists between shadow economy and the performance efficiency of small businesses.

2- A correlation exists between the narrow corporate culture of small business owners and the spread of shadow economy phenomenon.

3- There is a direct correlation between the shadow economy and an increase in numbers of semi-foreign owned small businesses.

4- A more effective electronic information network between national banks, the higher potential Information and Communication Technologies (ICTs) can empower these banks to more effectively monitor shadow economy activities. 
5- A more effective electronic communication network and an accurate shared governmental agencies' database will enable these entities to more effectively limit shadow economy activities.

6- There is a correlation between shadow economy, the decline of service quality of governmental agencies, the low standard of living and the devaluation of the national currency.

7- There is a direct correlation between the shadow economy and the criminal economy.

\subsection{The Concept of Shadow Economy}

Shadow economy activities are considered illegal activities that have been practiced by man from ancient times and throughout ancient and modern civilizations. The main characteristics of the shadow economy were stated in the International Labor Office $15^{\text {th }}$ report of 1993 as follows:

Shadow economy is a range of commercial and service activities that provide financial income and employment opportunities for their owners and operates under the shade of stealthy without permits from official bodies. These activities are in most cases illegitimate and represent a violation of the laws and moral values, and most of these organizations operate under administrative and technical systems which have a general nature of taxes evasion. According to Al-Julaydan (2012), the term 'shadow economy' is commonly associated with tax evasion activities that intend to subvert a state's tax system. Such activities may be characterized by an illegal nature, such as private teaching business, or may be legal businesses registered with official authorities. In both cases, business owners evade or avoid payment of taxes or reduce their tax liability. It may also be illegitimate businesses that generate income to their owners including trafficking in illicit goods, such as drug trafficking and counterfeit goods trade. Causes for the problems posed by the shadow economy mainly stem from the private sector's failure to provide employment for individuals and provide appropriately priced products. Some individuals, especially with low incomes and limited resources, have sought to provide for themselves and their families by taking on some kinds of illegal and illegitimate jobs. The Chamber of Commerce in the Eastern Province of the Kingdom of Saudi Arabia (2010) explains the shadow economy activities do not always necessarily include illegitimate and immoral businesses but they do include the day-to-day activities in some commercial and industrial undertakings such as commercial concealment, being one shadow economy activity. Commercial concealment has become a widely spread phenomenon in Saudi Arabia, where a citizen can enable a foreigner to conduct a business in violation of the country's residency regulations and laws. The citizen hereby becomes concealed, while the foreigner is able to use the citizen's name or commercial record to conduct business. Meanwhile, the resident does not abide by any regulatory framework or commercial law. In this sense, legitimate businesses often mingle with illegal acts, while registered businesses are operationally interwoven with operational aspects of non-registered businesses. External remittances sent abroad by persons involved in such activities could conceivably total billions of dollars. Fabric and footwear stores, restaurants, carpentry and blacksmith workshops, car maintenance shops, plumbing and electric services shops, laundry shops and electronic services stores, all represent examples of commercial and industrial activities that could be immersed in the shadow economy. These stores/shops operate through cash sales, which are not recorded and evade audit in state accounts. As mentioned by Saleh (2011), the foreign workers perform money laundering operations via issuing money orders of the money they get from illegal sources in order to legitimize them by hiding their sources and turning them into legitimate investments or business to mislead the official authorities.

\subsection{Factors Contributing to the Growth of Shadow Economy Activities}

The following reasons have contributed to the growth of shadow economy:

- The development of electronic communications networks and the Internet which has helped to speed up the pace of money smuggling.

- Reliance on human monitoring rather than the use of sophisticated electronic control systems to monitor tax evasion and evaders.

- The large number of foreign workers in Saudi Arabia.

- As noted by Al-Suhaimi (2011), the cultural attitudes and tendencies of citizens who fail to recognize the negative implications and impact of opposing compliance with laws and governmental regulations.

- The rise in unemployment and global inflation rates.

- Discrepancies and lack of legislative standardization between countries. 
- Competition between local and international banks to attract customers of various income levels and nationalities without verifying sources of funds.

- According to Sarayrah (2005), the shadow economy is correlated to money laundering activities which has proven to be a fertile breeding grounds for strong materialistic temptations. Non-registration of illegal generated revenues has permitted individuals to operate and engage in commercial sex activities.

- Deep-rooted administrative corruption of some individuals, especially those working in sensitive entities such as banking and judicial systems as per Abd (1999).

- Fiscal and monetary policies of some countries to encourage foreign investment regardless of its sources. Citizens working in other countries are allowed to transfer money to their home countries without being investigated concerning funds' sources. Some countries encourage and contribute to shadow economy activities due to their own economies' very low performance.

- The prevalence of internal conflicts, wars, poverty, famines, and migration. Refugees use all means to provide for a living and accept to work any profession at whatever cost.

- As explained by Ghamri (2009), expansion of the tourism sector has enabled cash-flow and ease of financial transfers required by individuals to enjoy their vacations. Moreover, travelling to engage in sexual activities has led to the prosperity of the global sex industry.

- Low salaries and wages in general and pensions in particular have forced individuals to look for additional incomes such as working as a taxi drivers or security guards. Such and similar jobs are not registered in the government system.

- Many foreigners work under cover in illegal trade activities via commercial concealment. In this sense, counterfeit goods, stolen and sub-standard goods are disposed of at low prices.

- The spread of seasonal work during the holy month of Ramadan and the month of Islamic pilgrimage to Mecca (Hajj). A large number of students, citizens and expatriates enter the country during these seasons to work in activities involving the service of pilgrims.

- Trading in visas and permitting the stay of foreign workers in the country without surveillance.

- Since The Kingdom of Saudi Arabia has a religious nature, individuals of various nationalities attempt to access the country during the Hajj and Umrah seasons and extend their stay to exercise illegal businesses.

- Unlike European and other industrial countries, The Kingdom of Saudi Arabia lacks a tax system. No taxes are levied on individuals based on income. The system of the Department of Zakat and Income Tax (DZIT) in Saudi Arabia is used to administer the private sector.

- Some third world countries do not possess the financial resources nor management expertise to combat transnational organized crime. This inevitably leads to tax evasion and money laundering activities.

- As reported by Marefa encyclopedia ("Offshore", n.d.), the growth of offshore areas and havens, where opportunities for tax evasion and deposits of stolen money are available and exploited.

- The scarcity of consumer goods and some personal services as per Boumediene \& Gharbi (2015)

\subsection{Activities and Practices Falling under the Scope of Shadow Economy}

- Undermining corporate profits in order to reduce tax burden; the action of bribery of tax officers (legitimate and illegal acts).

- Drug trafficking, weapon smuggling, goods, counterfeit products and fake currency across borders, sexual slavery/exploitation and human trafficking are all examples of illegal activities which are not recorded by the state. Accordingly, the state is unaware of organizations performing such activities and is unable to trace their tax payments (illegal businesses that are unregistered by the state and fall under the scope of criminal economy) as stated by Abdul-Salam (2002).

- Sums of money earned by employees in compensation for terminating government procedures ahead of time, or for the award of official contracts, or for providing confidential information about wealthy individuals or other critical information. Such amounts are not subject to taxes. 
- The abuse of state resources by employees in aspects other than those originally intended.

- Issuance of forged certificates such as medical certificates, fraudulent passports, and speculation in counterfeit stocks and bonds and counterfeit phone cards.

- Unrecorded, undocumented and unlicensed household labor force and temporary employment exercising business activities without the knowledge of relevant governmental bodies or under commercial concealment.

\subsection{The Negative Effects of Shadow Economy}

\subsubsection{First: The Economic Effects of Shadow Economy}

- Tax losses weaken the state balance-of-trade. Furthermore, money smuggling leads to liquidity shortage and a decline of sustainable development programs.

- Reduction of government spending on public facilities entails lower levels of education and health services; a case that poses threats to the citizens' welfare due the state's inability to generate sufficient employment opportunities.

- Higher taxes are imposed on honest citizens in order to enable the state to provide basic services as mentioned in the Economic and Social National Council pamphlets (2004)

- The growing demand for foreign currency (particularly US dollars) for smuggling purposes results in the increase of demand for foreign currency and reduces the demand for local currency, consequently leading to higher foreign currency exchange rates and the devaluation of the national currency. Inevitably the emergence of a black market is witnessed.

- Money transfers, as in the case of commercial concealment practiced by foreign workers, deprive the national economy of these funds, weaken national economic efficiency and impede investment.

- Distortion of the national economy, financial markets and banks gives a negative image to foreign investors thus leading to the loss of investment opportunities as noted by Al-Khuraisha (2006).

- The indulgent attitude of some countries to combat shadow economies may lead to political conflict amongst them. It may also result in conflicts with the International Monetary Fund (IMF) due to administrative corruption and low exchange rates.

- A change in consumer and productive behavior of individuals occurs. People become most likely focus-centered towards committing illegal acts such as drug trade or trading in illusive real estate, stocks, bonds and entities with less regard to trading in industrial goods.

- Unlawful acts and illegal businesses - including bribes, administrative corruption - may lead to the lack of trust in the integrity of banks, public and private institutions. Al-Sakka (2012) assured that capital flight and economic instability consequently occur when assets or money rapidly flow out of a country, not only sent by foreign investors but also by citizens.

- Despite all of the above, it has to be admitted that the shadow economy has some positive influences or effects. It provides employment opportunities for many individuals, especially unemployed young people, female household heads, domestic workers and low-income earners. These jobs can provide a transition to self-sufficient living and may generate work opportunities, as is the case with seasonal employment during Umrah and Hajj pilgrimage seasons.

- The informal sector serves as a reserve army of surplus labor that may be exploited by the formal sector during economic booms.

- Costs borne by the state as a result of money smuggling and tax evasion. The engagement of government agencies such as the police, courts and health facilities in combating fraudulent behavior and dishonest individuals.

- Due to the lack of sufficient information on industrial, agricultural and populated areas, as well as the true unemployment rate, investment opportunities remain unidentified.

- A serious degradation of hand-labor and deterioration in the level of skills of workers in the industrial sector due to the lack of vocational training opportunities. As a result, national products become unable to compete globally. 
- Informal unregistered workers are unable to take advantage of pension and retirement systems since they are not officially registered in government agencies.

- The absence of laws, regulations and management of assets lead informal workers to work in an unhealthy and unstable environment exposing them to potential psychological and physical abuse and exploitation due to lack of enforceable deterrent laws, for males and females.

- Difficulty to account for fuel, electricity and water consumption due to breaches of law.

- As explained by Nashed (2005) the spread of smuggled products whether in the form of illegal (such as alcohol and drugs) or legal products. Smuggling rates increase in countries affected by trade-bans thus leading to a sharp fluctuation in prices (in this example, informal economy may contribute to secure products needed by the formal sector).

- On the other hand, Al-Mutairi (2014) indicates that shadow economy is characterized by some high rate of returns as a result of tax evasion which should not be viewed as a plus as it negatively affects the national income.

- Agila, Bin Nawi \& Ghazeel (2007) discussed what could be relatively viewed as an advantage of the shadow economy which is providing a lot of individuals with employment opportunities, especially unemployed young people, female heads of households, home workers and low-income earners, where these jobs can provide self-sufficiency and contribute to job opportunities creation, as is the case in seasonal jobs in periods of Umra or Hajj.

\subsubsection{Second: The Social Effects of Shadow Economy}

- The occurrence of social structural changes since morally corrupt individuals amass enormous wealth via taxes evasion due to the bribery of officials who earn modest salaries and are unable to resist financial temptation and are therefore susceptible to and led into administrative corruption.

- As a result of tax fraud, especially associated with large companies, businessmen often have an upper hand for offering many services such as recruitment of staff and the appointment of loyal people to work for their patronage.

- Predominance of the culture of fraud, theft and embezzlement.

\subsection{The Size of Shadow Economy All over the World}

As illustrated by Owais (1995), the estimate of the size of shadow economy activities in the United States is around $\$ 500$ billion, while it reaches $\$ 50$ billion in Britain and around $\$ 331$ billion in Europe. The rest of the world accounts for $\$ 500$ billion for shadow economy activities. In African countries, shadow economy represents about $60 \%$ of GDP, while in Asia the percentage ranges to $40 \%$.

\section{Review of Literature}

In a study by Hayan (2006) entitled "Hidden Economy or Shadow Economy", the researcher focused on the main causes of shadow economy summarized in the following points: the weakness of the Syrian citizen's income; the high inflation rates lead to decrease real income value; irregular work as a result of increased number of workers who enter the labor market and evade payment of taxes, domestic labor, unregistered employment, the dominance of personal relationships, the economic recession, and the spread of the black market. The study also tackled some aspects of the shadow economy, including money smuggling, Individual exploitation of institutional positions, and administrative corruption. This study also focused on the role of money laundering in the diffusion of the shadow economy phenomenon in Syria. The study stated that money laundering activities include trade in weapons, drugs and organ trafficking. In another research by Bo-Dalal (2008) entitled "The problem of shadow economy in Algeria: Causes and Solutions", the researcher focused on statistical methods to measure the shadow economy. He mentioned two groups of estimation methods to assess the size of shadow economy. The first group is composed of direct approaches which employ either well-designed surveys and samples or tax auditing to assess shadow economy activities. These activities are summed up to reach an estimate of their relevant volume transactions (surveys and tax auditing direct method). The second group is composed of indirect approaches that attempt to identify the effects of shadow economy. Indirect Approaches include the following indicators:

The National Statistics indicator: the size of shadow economy is estimated based on the discrepancies between income and national expenditure statistics, or discrepancies between individualistic data and workforce statistics. 
The official and actual labor force indicator: the growth estimate in the size of shadow economy is based on the decline in participation of the labor force in the official economy. If total labor force participation is assumed to be constant, a decreasing official rate of participation can be seen as an indicator of an increase in the activities in the shadow economy. Therefore, the discrepancies between the actual participation rate and the recorded official rates may provide an estimate of the volume of irregular employment, thus estimating the size of shadow economy.

The transactions approach indicator: The data pertaining to the volume of transactions in the economy may be used to calculate the nominal and real GDP i.e. the formal and informal economy. Relating total nominal GDP to total transactions, the shadow economy GDP can be calculated by subtracting the official GDP from total nominal GDP. Additionally, the monetary approach considers the burden of taxation. In conclusion, it becomes evident by reviewing some of the previous studies that they were conducted in different conditions and environments and that they show the size of the shadow economy in the States of Syria and Algeria with an emphasis on statistical methods and concepts of the shadow economy while the current study is distinctive in focusing on the following aspects:

- The study focuses on the shadow economy from a legal perspective. It also necessitates identification of tax evaders and shadow economy operatives as criminals who must be brought to justice, prosecuted and deported.

- The study considers the shadow economy as one of the transnational organized crimes coordinated across national borders. It is one of the most pernicious crimes of the century due to its destructive effects on the economic, social, family and religious levels.

- The above-mentioned studies focused on the concern of previous researchers to study the Syrian and Algerian shadow economies; while the present study focuses on the study of shadow economy in the Kingdom of Saudi Arabia. It also sheds light on factors influencing the shadow economy such as the effect of foreign workers in violation of residency or work regulations who engage or invest in business activities using commercial concealment. While commercial concealment is considered one of the most prevalent negative occurrences in the Kingdom that threaten the national economy, both Syria and Algeria do not suffer from foreign labor violations or commercial concealment at the same rates as in Saudi Arabia.

- The study also focuses on the responsibilities borne by banks to combat the shadow economy, since commercial banks are eventually the recipients of deposited funds. The banks' roles constitute safe-havens for such activities. The study focuses on the role of banks in combating the shadow economy through several steps such as verifying the identity of its customers, investigating the employment conditions of workers who violate laws, ensuring the actual transfer beneficiaries, disclosing confidential information in doubtful cases, and immediate reporting to official authorities to curb criminality. Due to the difficulty of detecting individuals engaged in the shadow economy, particularly because of time and effort consumed in information analysis, the study sets out a system to ensure an accurate record of data following strict recording, saving and updating rules on a regular basis.

- Finally, the analysis of the effect of small businesses is intended to reduce the spread of the shadow economy.

- It is necessary to establish a specialized department to combat the shadow economy by detecting money laundering activities. This department should have and exercise all the necessary powers and perform all its assigned duties. It should be manned by highly-qualified of experts in fields related to money laundering. The department is intended to assist and advise all state institutions including the Ministry of Interior and the Saudi Arabian Monetary Agency and the Chairman of the Capital Market Authority.

\section{Data Analysis and Interpretation}

This part of the study aims to diagnose the relationship between the shadow economy phenomenon and small businesses' performance efficiency. The study also investigates the factors that led to the spread of the shadow economy phenomenon in the Saudi economy. It also aims to set out some solutions to limit the future growth of this phenomenon. To achieve these goals, data has been collected by means of a questionnaire specifically designed for the study purpose. The questionnaire was distributed over a sample of the targeted population. 137 individuals, male and female, responded to the questionnaire. The Statistical Package for the Social Sciences (SPSS®) computer program, version 20.0, was used to analyze the collected data. Appropriate statistical indexes were used to analyze the data including replicates, percentages/frequencies and arithmetic mean (average) to summarize and rank specific observations throughout the questionnaire. Pearson's correlation coefficient, $r$, was used to test the study hypotheses. These hypotheses are:

1. A correlation exists between the shadow economy and the performance efficiency of small businesses. 
2. A correlation exists between the narrow corporate culture of small business owners and the spread of the shadow economy phenomenon.

3. There is a direct correlation between the shadow economy and an increase in numbers of semi-foreign owned small businesses.

4. A more effective electronic information network between national banks, the higher potential Information and Communication Technologies (ICTs) can empower these banks to more effectively monitor shadow economy activities.

5. A more effective electronic communication network and an accurate shared governmental agencies' database will enable these entities to more effectively limit shadow economy activities.

6. There is a correlation between the shadow economy, the decline of service quality of governmental agencies, low standards of living and the devaluation of the national currency.

7. There is a direct correlation between the shadow economy and the criminal economy.

Based on the above, the study's data analysis scenario is based on following perception:

First: $\quad$ Analyze the sample's demographic characteristics.

Second: $\quad$ Test the study hypotheses.

Third: $\quad$ Identify statistically significant differences in how different individuals answered the questionnaire due to different sample demographic characteristics.

Fourth: $\quad$ Reach a conclusion of the most prominent study results.

The following section contains the study's data analysis and interpretation:

\subsection{First: A Profile of the Demographic Characteristics of the Sample}

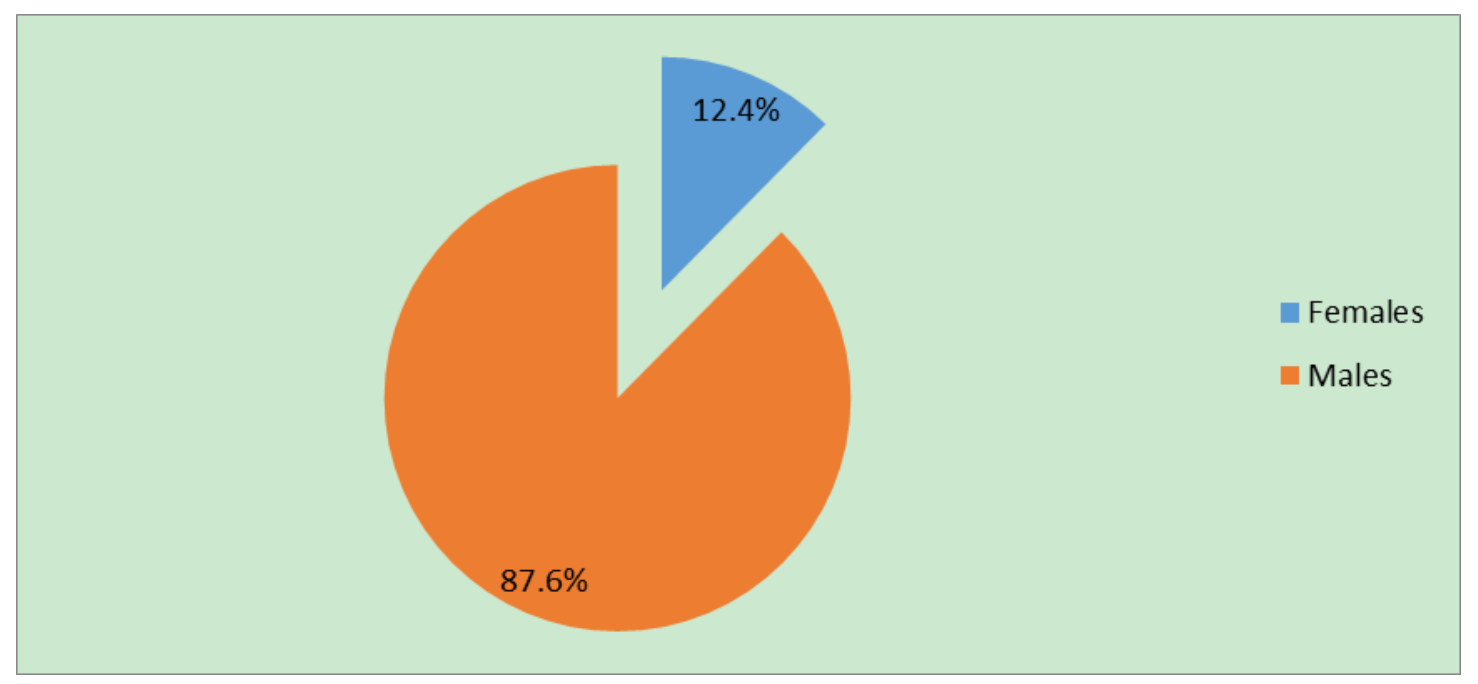

Diagram 1. Classification of the sample according to gender

It is clear from the above diagram that male participants outnumber females in the sample at $87.6 \%$ compared to $12.4 \%$. This situation is replicated in other regional studies due to the difficulty of obtaining feedback from females in surveys. 


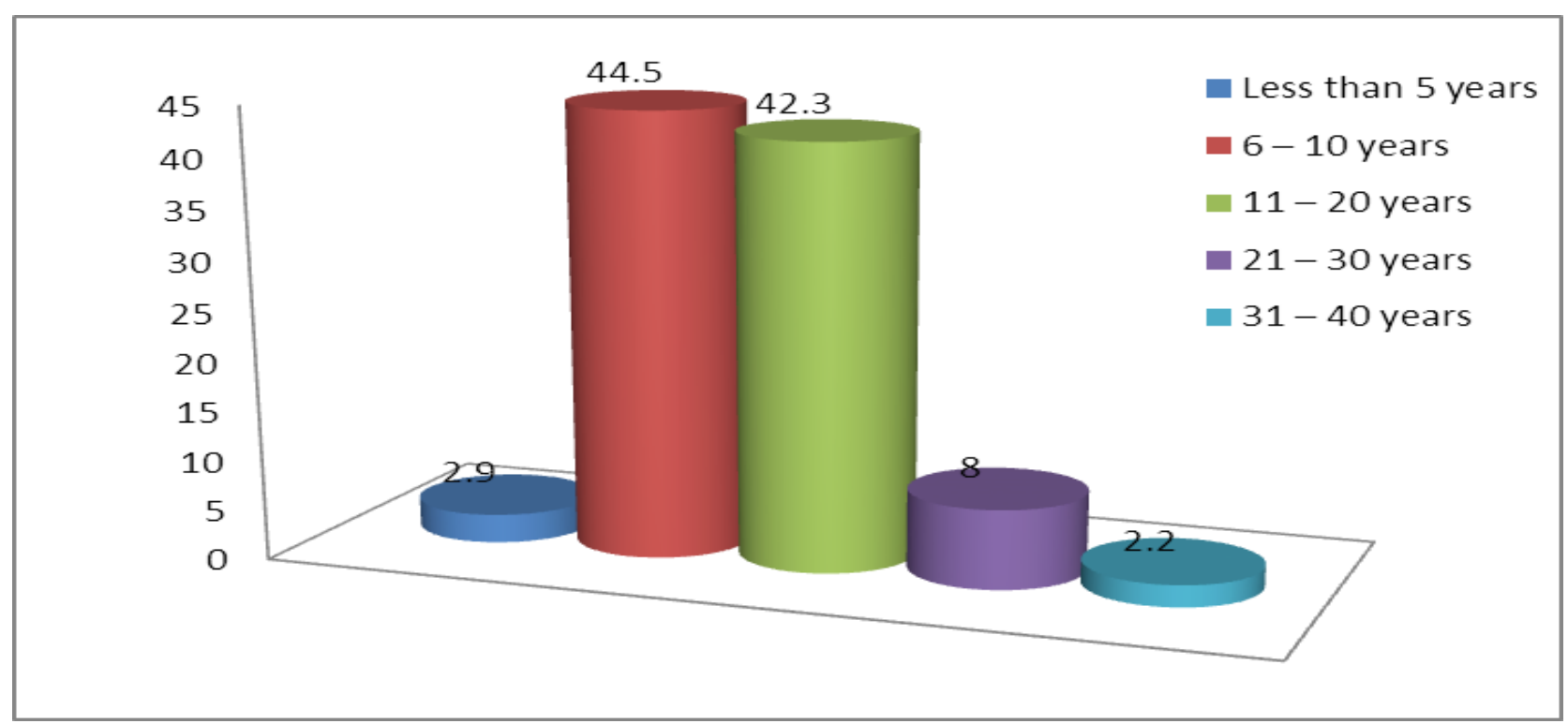

Diagram 2. Classification of the sample according to the years of previous experience

It is clear from the above diagram that $2.9 \%$ of the respondents participating in this study have less than 5 years of experience, $44.5 \%$ have a range between 6-10 years of experience, $42.3 \%$ have a range between 11-20 years of experience, $8.0 \%$ have a range between 21-30 years of experience, while only 2.2\% have a range between 31-40 years of experience. Accordingly, we conclude that the majority of respondents participating in this study have a range between 6-20 years of experience, representing $86.8 \%$ of the total sample, which provides the appropriate years of experience required to assess the shadow economy phenomenon.

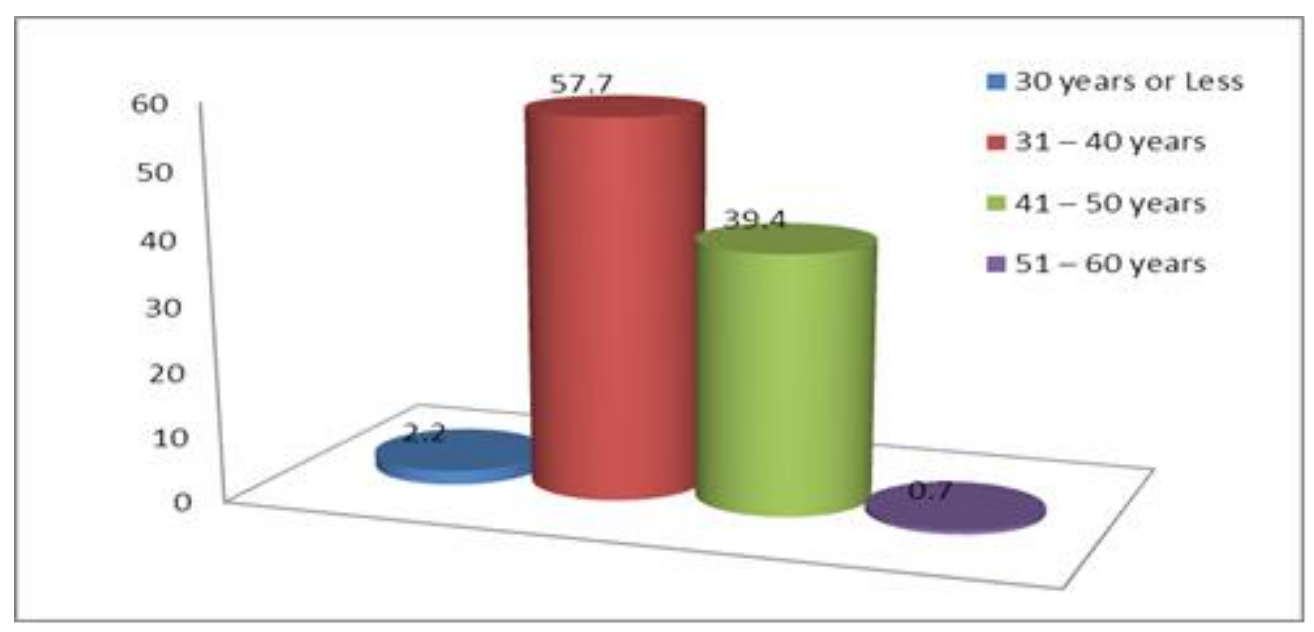

Diagram 3. Classification of the sample according to the age variable

It is clear from the above diagram that $2.2 \%$ of the respondents participating in this study are 30 years old or less, $57.7 \%$ are between $31-40$ years old, $39.4 \%$ are between $41-50$ years old, while only one individual is between 51-60 years old. Thus, we conclude that the majority of respondents participating in this study are between 31-40 years old, which is classified as young people in the employment field, followed by the age group ranging between 41-50 years representing $39.4 \%$ of the total sample size. 


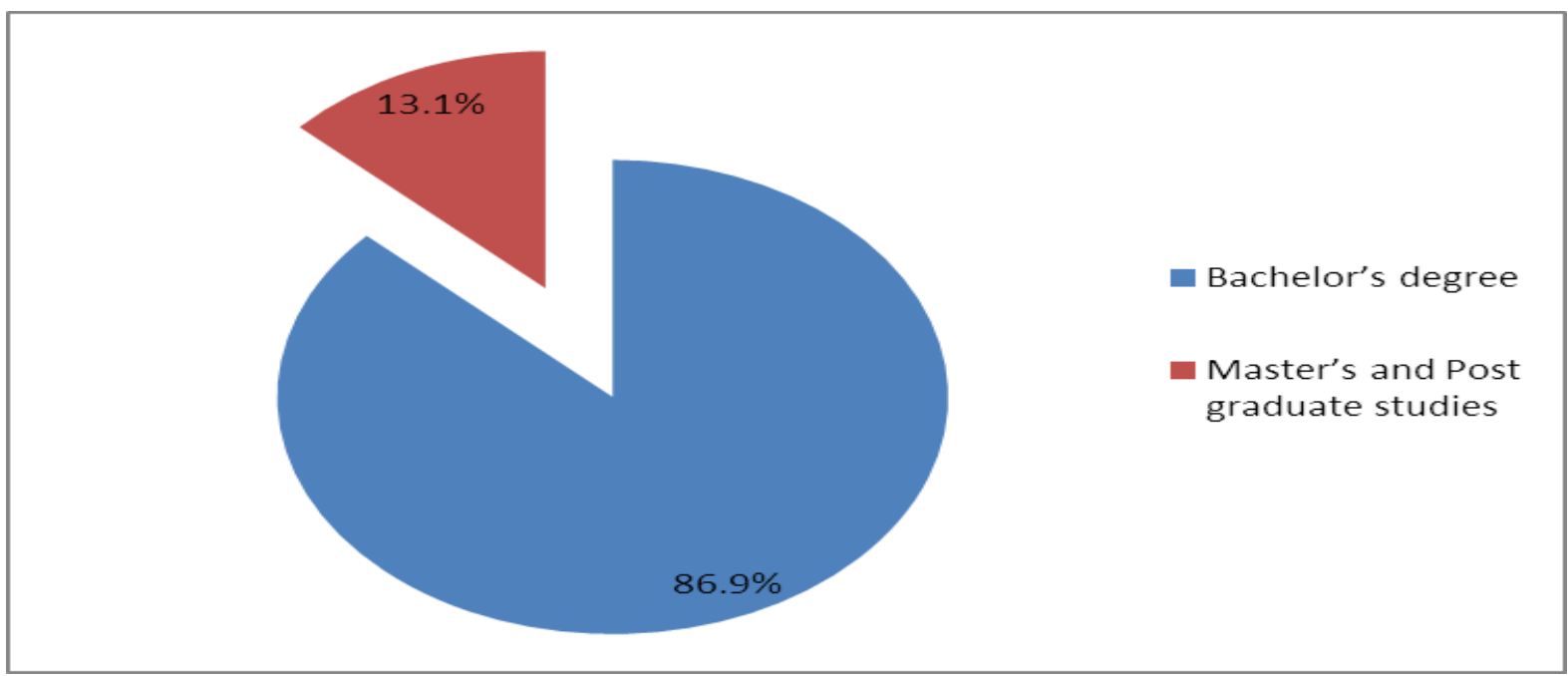

Diagram 4. Highest academic qualificaitons of the participants

It is clear from the above diagram that the majority of the participants in this study hold bachelor's degrees, at $86.9 \%$ of the total sample size, while $13.1 \%$ hold Master's degrees or are admitted to post graduate studies. Accordingly, the qualifications of the majority of the sample are consistent with the nature of the study and its objectives. It is expected that the questioned sample provide adequate information concerning the shadow economy phenomenon, as well as the factors contributing to the growth of this phenomenon in the Saudi economy.

\subsection{Second: The Results of Testing the Hypotheses}

\subsubsection{The First Hypothesis}

"A correlation exists between shadow economy and the performance efficiency of small businesses".

Table 1. Display of the average score and arithmetic mean to the questionnaire on the performance efficiency of small businesses

\begin{tabular}{|c|c|c|c|c|c|c|c|}
\hline & $\begin{array}{l}\text { Strongly } \\
\text { Agree }\end{array}$ & Agree & Neutral & Disagree & $\begin{array}{l}\text { Strongly } \\
\text { disagree }\end{array}$ & $\begin{array}{l}\text { The } \\
\text { Mean }\end{array}$ & $\begin{array}{l}\text { Standard } \\
\text { deviation }\end{array}$ \\
\hline $\begin{array}{l}\text { Tax evasion leads to a reduction } \\
\text { in government spending and thus } \\
\text { lower levels of medical, } \\
\text { educational and social services } \\
\text { are provided. }\end{array}$ & 38.0 & 55.5 & 4.4 & 2.2 & 0.0 & 4.29 & 0.66 \\
\hline $\begin{array}{l}\text { The financial crisis and the high } \\
\text { standard of living have given rise } \\
\text { to tax evasion. }\end{array}$ & 32.1 & 62.0 & 3.6 & 2.2 & 0.0 & 4.24 & 0.63 \\
\hline $\begin{array}{l}\text { Due to the large number of small } \\
\text { businesses often dealing through } \\
\text { cash transactions and not through } \\
\text { networks, its revenues are } \\
\text { difficult to monitor thus } \\
\text { contributing to tax evasion. }\end{array}$ & 29.9 & 62.8 & 5.8 & 1.5 & 0.0 & 4.21 & 0.61 \\
\hline $\begin{array}{l}\text { Shadow economy has } \\
\text { contributed in unemployment }\end{array}$ & 23.4 & 67.2 & 6.6 & 2.9 & 0.0 & 4.11 & 0.64 \\
\hline \multicolumn{6}{|c|}{ The Weighted Average } & 4.21 & 0.64 \\
\hline
\end{tabular}


It is clear from the results shown in Table 1 that the sample indicates that shadow economy, represented in the growing rate of small businesses in the Kingdom, mainly gives rise to tax evasion. The latter consequently leads to a reduction in government spending and thus a lower level of medical, educational and social services provision. The shadow economy has actually led to increased unemployment rates since it does not contribute to secure employment for job-seekers. This outcome is supported by the Weighted Average of 4.21 and a standard deviation of 0.64 . We can also conclude the following from the indicators in the above table:

With respect to the question "Tax evasion leads to a reduction in government spending and thus lower levels of medical, educational and social services are provided", the respondents' answers indicate that $93.5 \%$ of the sample strongly agree. The results shown in the Table also indicate that the financial crisis and the high standard of living have given rise to tax evasion, where $94.1 \%$ have consented to this statement due to the negative effects of the financial crisis and the high standard of living in causing price rises in the Saudi market. The results also show that $92.7 \%$ of the sample participants agree that the large number of small businesses, frequently dealing through cash transactions and not through networks, have led to the difficulty in monitoring its revenues and thus helped tax evasion. The results also indicate that $90.6 \%$ of the sample participants agree that the shadow economy is a major factor causing extensive youth unemployment, since the vast majority of owners and managers of small businesses are foreigners. To test the validity of the first hypothesis of the study, Pearson's Correlation Coefficient, $r$, was used as shown in Table 2 below:

Table 2. The relationship between the shadow economy and the performance efficiency of small businesses

\section{Correlations}

\begin{tabular}{ccll}
\hline Performance efficiency of small businesses & $\begin{array}{c}\text { Shadow } \\
\text { Economy }\end{array}$ & & \\
\hline $.168^{*}$ & 1 & Pearson Correlation & \\
0.49 & & Sig. (2-tailed) & Shadow Economy \\
137 & 137 & N & \\
1 & $.168^{*}$ & Pearson Correlation & Performance efficiency of \\
& .049 & Sig. (2-tailed) & small businesses \\
137 & 137 & N & \\
\hline
\end{tabular}

*Correlation is significant at the 0.01 level (2-tailed)

It is clear from the results shown in the above Table that the value of Pearson's Correlation Coefficient, $r$, between the shadow economy and the performance efficiency of small businesses is 0.168 and is statistically significant at the 0.049 level. Therefore, we conclude that a positive correlation exists and there is a statistically significant relationship between the shadow economy and the performance efficiency of small businesses in the Saudi economy. The persuasive justification of this relationship can contribute to tax evasion of small business owners which has led to growth of their profits, thus resulting in the expansion of these businesses and the increase of their volume.

\subsection{Testing the Validity of the Second Hypothesis}

"A correlation exists between the narrow corporate culture of small business owners and the spread of the shadow economy phenomenon".

Table 3. Display of the average score and arithmetic mean to the questionnaire on the corporate culture of businessmen and the spread of shadow economy

\begin{tabular}{lccccccc}
\hline & $\begin{array}{c}\text { Strongly } \\
\text { Agree }\end{array}$ & Agree & Neutral & Disagree & $\begin{array}{c}\text { Strongly } \\
\text { disagree }\end{array}$ & The Mean & $\begin{array}{c}\text { Standard } \\
\text { deviation }\end{array}$ \\
\hline $\begin{array}{l}\text { Set up a national minimum } \\
\text { wage order especially for small } \\
\text { businesses. }\end{array}$ & 27.7 & 64.2 & 6.6 & 1.5 & 0.0 & 4.18 & 0.61 \\
\hline $\begin{array}{l}\text { Activate the legislative role and } \\
\text { revisit work labor laws. }\end{array}$ & 27.7 & 66.4 & 3.6 & 2.2 & 0.0 & 4.20 & 0.60 \\
\hline
\end{tabular}


Increase the role of social

security funds and combat

27.0

66.4

4.4

2.2

0.0

4.18

0.61

Encourage young men and women to engage in micro-enterprise and craft 26.3 70.1 3.6

0.0

0.0

4.21

0.50

businesses.

Freeze foreign recruitment due to the increase in number of expatriates working in small 63.5 4.4

0.0

4.23

0.62

businesses and tax evaders.

In cases where non-registered workers at the Ministry of Labor and those lacking residence permits conduct their private owned and small businesses, they do not have

$34.3 \quad 59.9 \quad 5$
5.

0.7

0.0

4.27

0.62

trade licenses to carry on business, therefore they evade paying taxes.

The shadow economy contributes in doubling the volume of counterfeit and illegal goods, especially in small businesses.

$\begin{array}{lllllll}34.3 & 62.0 & 2.2 & 1.5 & 0.0 & 4.29 & 0.58\end{array}$

It is clear from the results of the above Table that the majority of questionnaire respondents for this section agree on the narrow nature of the corporate culture of small business owners. The pervasiveness of this culture has led individuals conducting these businesses to engage in shadow economy activities such as trade in counterfeit goods and tax evasion since they are not registered at the Ministry of Labor. This result is supported by the Weighted Average of 4.22 and a standard deviation of 0.59 . Therefore, we can conclude from the above that remedies for this situation are necessary including taking the following measures: Set up a national minimum wage order for these kinds of businesses; Activate the legislative role and revisit work labor laws; Increase the role of social security funds and combat poverty; Encourage the youth to engage in small businesses through State support; Freeze foreign recruitment and illegal visa trading in the black market. To test the validity of second hypothesis, Pearson's Correlation Coefficient, r, was used as shown in Table 4 below:

Table 4. A correlation exists between the narrow corporate culture of small business owners and the spread of the shadow economy phenomenon

\section{Correlations}

\begin{tabular}{ccll}
\hline $\begin{array}{c}\text { The narrow corporate culture of small } \\
\text { business owners }\end{array}$ & $\begin{array}{c}\text { Shadow Economy } \\
\text { Phenomenon }\end{array}$ & \\
\hline $333^{*}$ & 1 & Pearson Correlation & Shadow Economy Phenomenon \\
.000 & 137 & $\mathrm{~N}$ & Sig. (2-tailed) \\
137 & $.333^{*}$ & Pearson Correlation & Narrow corporate culture small \\
1 & .000 & Sig. (2-tailed) & business owners \\
& 137 & $\mathrm{~N}$ & \\
\hline
\end{tabular}

*Correlation is significant at the 0.01 level (2-tailed) 
It is clear from the above Table that the value of Pearson's Correlation Coefficient, $r$, between the narrow corporate culture of small business owners and the spread of the shadow economy phenomenon is 0.333 and is statistically significant at the 0.01 level. Therefore, we conclude that a positive correlation exists between the narrow corporate culture of small business owners and the spread of the shadow economy phenomenon. This gives rise to another emergent phenomenon namely, commercial concealment. Foreign workers engaged in small businesses are sponsored by Saudi citizens (under the sponsorship "Kafala" system) who are keen to prolong the stay of those foreigners due to mutual interests. Notwithstanding the negative effects of the spread of businesses conducted under the shadow economy which does not contribute in the development of State services due to inherent tax evasion.

\subsection{Testing the Validity of the Third Hypothesis}

'There is a direct correlation between the shadow economy and an increase in numbers of semi-foreign owned small businesses.'

Table 5. Display of the average score and arithmetic mean in the questionnaire related to the tendency of semi-foreign owned small businesses to increase in frequency and number

\begin{tabular}{|c|c|c|c|c|c|c|c|}
\hline & $\begin{array}{l}\text { Strongly } \\
\text { Agree }\end{array}$ & Agree & Neutral & Disagree & $\begin{array}{l}\text { Strongly } \\
\text { disagree }\end{array}$ & $\begin{array}{l}\text { The } \\
\text { Mean }\end{array}$ & $\begin{array}{l}\text { Standard } \\
\text { deviation }\end{array}$ \\
\hline $\begin{array}{l}\text { Use biometric identification to } \\
\text { control the entry of workers } \\
\text { violating the laws so as to } \\
\text { prohibit them from returning to } \\
\text { the Kingdom in cases where } \\
\text { violation reoccurs. }\end{array}$ & 27.0 & 65.7 & 3.6 & 3.6 & 0.0 & 4.16 & 0.66 \\
\hline $\begin{array}{l}\text { The communications revolution } \\
\text { and new technologies have } \\
\text { opened-up new opportunities } \\
\text { and loopholes for tax evasion } \\
\text { since millions of daily } \\
\text { transactions are difficult to } \\
\text { control. Moreover, tax evaders } \\
\text { use Internet applications and } \\
\text { smart cards. }\end{array}$ & 25.5 & 67.9 & 4.4 & 2.2 & 0.0 & 4.17 & 0.60 \\
\hline $\begin{array}{l}\text { The informal economy secures } \\
\text { additional income to individuals } \\
\text { who work in the government } \\
\text { sector and own their private } \\
\text { small businesses. }\end{array}$ & 21.2 & 70.8 & 5.1 & 2.9 & 0.0 & 4.10 & 0.61 \\
\hline \multicolumn{6}{|c|}{\begin{tabular}{|l} 
The Weighted Average \\
\end{tabular}} & 4.14 & 0.62 \\
\hline
\end{tabular}

It is clear from the results of Table 5 that the questionnaire respondents indicate that there is a tendency of semi-foreign owned small businesses to increase in frequency and number in the Saudi economy. This result is supported by the Weighted Average of 4.14 and a standard deviation of 0.62 . Therefore, it is clear that the tendency of semi-foreign owned small businesses to increase in frequency and number in the Saudi economy is mainly due to the following reasons:

The communications revolution and new technologies have opened-up new opportunities and loopholes for tax evasion since millions of daily transactions are difficult to control, especially as such transactions are often conducted by means of internet applications and smart cards. The informal economy secures additional income to individuals who work in the government sector and own their private small businesses. Those individuals find sufficient time to manage and supervise their businesses since they are the prime beneficiaries. Therefore, the shadow economy encourages the increase of these types of businesses. Accordingly, the researcher proposes the use of biometric identification to control the entry of workers violating the laws so as to prohibit them from returning to 
the Kingdom in cases where violations reoccur. To test the validity of the third hypothesis, Pearson's Correlation Coefficient, $r$, was used as shown in the Table below:

Table 6. Testing the relation between shadow economy and the tendency of semi-foreign owned small businesses to increase in frequency

\section{Correlations}

\begin{tabular}{|c|c|c|c|}
\hline Shadow Economy Phenomenon & $\begin{array}{l}\text { The tendency of } \\
\text { semi-foreign owned } \\
\text { small businesses to } \\
\text { increase in frequency }\end{array}$ & & \\
\hline $.378^{*}$ & 1 & Pearson Correlation & \multirow{4}{*}{$\begin{array}{c}\text { The tendency of semi-foreign } \\
\text { owned small businesses to } \\
\text { increase in frequency }\end{array}$} \\
\hline .000 & & Sig. (2-tailed) & \\
\hline 137 & 137 & $\mathrm{~N}$ & \\
\hline 1 & $.378^{*}$ & Pearson Correlation & \\
\hline & .000 & Sig. (2-tailed) & \multirow[t]{2}{*}{$\begin{array}{c}\text { Shadow Economy } \\
\text { Phenomenon }\end{array}$} \\
\hline 137 & 137 & $\mathrm{~N}$ & \\
\hline
\end{tabular}

*Correlation is significant at the 0.01 level (2-tailed)

It is clear from the above Table that the value of Pearson's Correlation Coefficient, $r$, between the shadow economy and the tendency of semi-foreign owned small businesses to increase in frequency and number is 0.378 and is statistically significant at the 0.01 level. Accordingly, we conclude that there is a statistically significant positive correlation between the shadow economy and the tendency of semi-foreign owned small businesses to increase in frequency and number in the Saudi economy. The most prominent factors that contribute to this result are the following:

- The communication revolution;

- The informal economy secures additional income to individuals who work in the government sector and own their private small businesses managed by foreigners sponsored by them or by their spouses or their relatives.

\subsection{Testing the Validity of the Fourth Hypothesis}

'A more effective electronic information network between national banks, the higher potential Information and Communication Technologies (ICTS) can empower these banks to more effectively monitor shadow economy activities.'

Table 7. Display of the average score and arithmetic mean to the questionnaire related to the importance of the existence of a more effective electronic information network between national banks that can empower these banks to more effectively monitor shadow economy activities.

\begin{tabular}{llcccccc}
\hline & $\begin{array}{c}\text { Strongly } \\
\text { Agree }\end{array}$ & Agree & Neutral & Disagree & $\begin{array}{c}\text { Strongly } \\
\text { disagree }\end{array}$ & $\begin{array}{c}\text { The } \\
\text { Mean }\end{array}$ & $\begin{array}{c}\text { Standard } \\
\text { deviation }\end{array}$ \\
\hline $\begin{array}{l}\text { External remittances may } \\
\text { exercised by foreigners and } \\
\text { Saudi citizens. }\end{array}$ & 16.8 & 70.1 & 3.6 & 5.8 & 3.6 & 3.91 & 0.87 \\
\hline
\end{tabular}


Electronic monitoring of all transactions performed by citizen owners of small businesses to combat tax $10.2 \quad 78.1 \quad 3.6$ 5.8 2.2 3.88 0.75 evasion.

Creation of a specialized department involving banks, Ministry of Interior and Custom Duties for the archiving of electronic files related to foreign $\begin{array}{lllllll}28.5 & 66.4 & 2.9 & 2.2 & 0.0 & 4.09 & 0.71\end{array}$ owners of small businesses in case they evade payment of taxes.

Comparing the income of individuals to the size of their bank accounts and the deposited 29.9

$\begin{array}{llllll}65.9 & 3.6 & 1.5 & 0.0 & 4.21\end{array}$

0.60 funds.

\begin{tabular}{|c|c|c|c|c|c|c|c|}
\hline $\begin{array}{l}\text { Knowledge of the true } \\
\text { beneficiary. }\end{array}$ & 31.4 & 63.5 & 3.6 & 1.5 & 0.0 & 4.23 & 0.59 \\
\hline Reporting on doubtful cases. & 24.8 & 65.0 & 5.1 & 5.1 & 0.0 & 4.2 & 0.64 \\
\hline Proceed to regularly update data. & 29.9 & 63.5 & 3.6 & 2.9 & 0.0 & 4.25 & 0.59 \\
\hline $\begin{array}{l}\text { The importance to raise } \\
\text { awareness and understanding } \\
\text { among citizens, put emphasis on } \\
\text { the prohibition of legal } \\
\text { interpretation by individuals, and } \\
\text { compelling residents to respect } \\
\text { the system and social values. }\end{array}$ & 29.9 & 63.5 & 3.6 & 2.2 & 0.7 & 4.20 & 0.67 \\
\hline $\begin{array}{l}\text { Small companies and businesses } \\
\text { that evade payment of taxes } \\
\text { benefit by doing so to reduce the } \\
\text { prices of their products and } \\
\text { increase their profits and } \\
\text { competitiveness. }\end{array}$ & 30.7 & 63.5 & 3.6 & 2.2 & 0.0 & 4.23 & 0.62 \\
\hline \multicolumn{6}{|c|}{ The Weighted Average } & 4.13 & 0.67 \\
\hline
\end{tabular}

It is clear from the results of the Table 7 that the questionnaire respondents for this section strongly agree that the effective existence of an electronic information network between national banks contributes in monitoring shadow economy activities. This result is supported by the Weighted Average of 4.13 and a standard deviation of 0.67 . The following points represent the most prominent features of the effectiveness of an electronic information network between national banks to empower monitoring of shadow economy activities:

Proceed to regularly update data; Knowledge of the true/actual beneficiaries from the profits of these businesses; Comparing the income of individuals to the size of their bank accounts and the deposited funds; Reporting on doubtful cases; The importance to raise awareness and understanding among citizens, put emphasis on the prohibition of legal interpretation by individuals, and compelling residents to respect the system and social values. To test the validity of the hypothesis that a more effective electronic information network between national banks can empower these banks to more effectively monitor shadow economy activities, Pearson's Correlation Coefficient, $r$, was used as shown in the Table below: 
Table 8. A more effective electronic information network between national banks can empower these banks to more effectively monitor shadow economy activities

\section{Correlations}

\begin{tabular}{|c|c|c|c|}
\hline $\begin{array}{l}\text { Shadow Economy } \\
\text { Phenomenon }\end{array}$ & $\begin{array}{l}\text { A more effective electronic } \\
\text { information network between } \\
\text { national banks can empower these } \\
\text { banks to more effectively monitor } \\
\text { shadow economy activities. }\end{array}$ & & \\
\hline $.531^{*}$ & 1 & Pearson Correlation & \multirow[b]{2}{*}{$\begin{array}{c}\text { The effective existence of } \\
\text { an electronic information } \\
\text { network between national } \\
\text { banks contributes in } \\
\text { monitoring shadow } \\
\text { economy activities }\end{array}$} \\
\hline $\begin{array}{l}.000 \\
137\end{array}$ & 137 & $\begin{array}{l}\text { Sig. (2-tailed) } \\
\mathrm{N}\end{array}$ & \\
\hline 137 & $\begin{array}{l}.531 * \\
.000 \\
137\end{array}$ & $\begin{array}{l}\text { Pearson Correlation } \\
\text { Sig. (2-tailed) }\end{array}$ & \multirow[t]{2}{*}{$\begin{array}{c}\text { Shadow Economy } \\
\text { Phenomenon }\end{array}$} \\
\hline & 137 & $\mathrm{~N}$ & \\
\hline
\end{tabular}

* Correlation is significant at the 0.01 level (2-tailed)

It is clear from Table 8 that the value of Pearson's Correlation Coefficient, $r$, between monitoring shadow economy activities and the effective existence of an electronic information network is 0.531 and is statistically significant at the 0.01 level. Accordingly, we conclude that there is a statistically significant correlation between the effective existence of an electronic information network between national banks and the monitoring of shadow economy activities. Therefore, the more effective an electronic information network is between national banks, results in increased levels of monitoring of shadow economy activities; which consequently lead to limit the increase of fake small businesses semi-owned by foreigners and concealed by some citizens.

\subsection{Testing the Validity of the Fifth Hypothesis}

'A more effective electronic communication network and an accurate shared governmental agencies' database will enable these entities to more effectively limit shadow economy activities.'

Table 9. Display of the average score and arithmetic mean to the questionnaire related to a more effective electronic communication network and an accurate shared governmental agencies' database will enable these entities to more effectively limit shadow economy activities

\begin{tabular}{|c|c|c|c|c|c|c|c|}
\hline & $\begin{array}{l}\text { Strongly } \\
\text { Agree }\end{array}$ & Agree & Neutral & Disagree & $\begin{array}{l}\text { Strongly } \\
\text { disagree }\end{array}$ & $\begin{array}{l}\text { The } \\
\text { Mean }\end{array}$ & $\begin{array}{l}\text { Standard } \\
\text { deviation }\end{array}$ \\
\hline $\begin{array}{l}\text { Monitor communications, } \\
\text { telephone calls and e-mail } \\
\text { communication of suspected } \\
\text { individuals. }\end{array}$ & 31.4 & 62.0 & 2.9 & 3.6 & 0.0 & 4.21 & 0.67 \\
\hline $\begin{array}{l}\text { Notify real estate owners of the } \\
\text { necessity to record lease } \\
\text { contracts entered with foreign } \\
\text { workers at the Ministry of } \\
\text { Interior in order to monitor their } \\
\text { geographic movements. }\end{array}$ & 21.9 & 67.9 & 8.0 & 2.2 & 0.0 & 4.09 & 0.62 \\
\hline
\end{tabular}


Investigative the rental of houses by citizens and foreigners during the Hajj and

24.8

62.8

10.2

2.2

0.0

4.1

0.66

Ramadan seasons

\begin{tabular}{|c|c|c|c|c|c|c|c|}
\hline $\begin{array}{l}\text { Electronic monitoring of } \\
\text { imported goods in terms of } \\
\text { origin, quality and compliance } \\
\text { with ministry specifications. }\end{array}$ & 29.2 & 64.2 & 5.8 & 0.7 & 0.0 & 4.22 & 0.58 \\
\hline $\begin{array}{l}\text { Surveillance of Customs } \\
\text { officers to reduce } \\
\text { cash } \\
\text { smuggling of foreigners. }\end{array}$ & 25.5 & 66.4 & 6.6 & 1.5 & 0.0 & 4.16 & 0.60 \\
\hline $\begin{array}{l}\text { Monitoring foreign teachers } \\
\text { who rent apartments for the } \\
\text { purpose of giving private } \\
\text { lessons to students without work } \\
\text { permits and consequently evade } \\
\text { taxes. }\end{array}$ & 26.3 & 65.7 & 5.8 & 2.2 & 0.0 & 4.16 & 0.62 \\
\hline $\begin{array}{l}\text { Replace passports of foreigners } \\
\text { with smart cards, similar to } \\
\text { Mobile SIM cards, to monitor } \\
\text { their movements and link them } \\
\text { to some official entities. }\end{array}$ & 28.5 & 64.2 & 4.4 & 2.9 & 0.0 & 4.18 & 0.64 \\
\hline $\begin{array}{l}\text { Create an electronic file for each } \\
\text { foreigner at relevant } \\
\text { governmental bodies including } \\
\text { information input received from } \\
\text { various entities such as bank } \\
\text { deposits, accommodation } \\
\text { address, places of medical } \\
\text { treatment and trips between } \\
\text { cities. }\end{array}$ & 33.6 & 64.2 & 0.7 & 1.5 & 0.0 & 4.3 & 0.56 \\
\hline $\begin{array}{l}\text { Monitor Guests in hotels and } \\
\text { furnished apartments. }\end{array}$ & 29.9 & 65.7 & 2.9 & 1.5 & 0.0 & 4.24 & 0.58 \\
\hline $\begin{array}{l}\text { Monitor transportation and } \\
\text { aviation lines }\end{array}$ & 32.1 & 61.3 & 4.4 & 2.2 & 0.0 & 4.23 & 0.63 \\
\hline $\begin{array}{l}\text { International cooperation with } \\
\text { security bodies in the native } \\
\text { countries of foreigners. }\end{array}$ & 31.4 & 62.8 & 4.4 & 1.5 & 0.0 & 4.24 & 0.60 \\
\hline Biometric Identification & 35.0 & 62.0 & 2.2 & 0.7 & 0.0 & 4.31 & 0.55 \\
\hline \multicolumn{6}{|c|}{ The Weighted Average } & 4.20 & 0.61 \\
\hline
\end{tabular}

It is clear from the results of Table 9 that the majority of questionnaire respondents for this section agree that the effective existence of an electronic communication network and an accurate database between governmental agencies helps in limiting shadow economy activities. This result is supported by the Weighted Average of 4.20 and a standard deviation of 0.61 . The researcher concludes from the results of Table (9) that the most effective means to reduce the shadow economy phenomenon are summed up in the following points:

- Biometric identification

- Create an electronic file for each foreigner at relevant governmental bodies including information input received from various entities such as bank deposits, accommodation address, places of medical treatment and trips between cities.

- Monitor guests in hotels and furnished apartments. 
- International cooperation with security bodies in foreigners' native countries.

- Monitor transportation and aviation lines

- Electronic monitoring of imported goods in terms of origin, quality and compliance with ministry specifications.

- Monitor communications, telephone calls and e-mail communication of suspected individuals.

These results are supported by the Mean (4.31, 4.30, 4.24, 4.24, 4.23, 4.22 and 4.21) consecutively. To investigate the role of a more effective electronic communication network and an accurate shared governmental agencies database to enable these entities to more effectively limit shadow economy activities, Pearson's Correlation Coefficient, $r$, was used as shown in the Table below:

Table 10. Testing the role of a more effective electronic communication network and an accurate shared governmental agencies' database to enable these entities to more effectively limit shadow economy activities

\section{Correlations}

\begin{tabular}{cclc}
\hline $\begin{array}{c}\text { Existence of an electronic } \\
\text { communication network and an } \\
\text { accurate shared governmental } \\
\text { agencies' database }\end{array}$ & $\begin{array}{c}\text { Shadow Economy } \\
\text { Phenomenon }\end{array}$ & \\
\hline $542^{*}$ & 1 & Pearson Correlation & Shadow Economy \\
.000 & & Sig. (2-tailed) & $\begin{array}{c}\text { Phenomenon } \\
137\end{array}$ \\
1 & $.542^{*}$ & $\begin{array}{l}\text { Pearson Correlation } \\
\text { Sig. (2-tailed) }\end{array}$ & $\begin{array}{c}\text { Existence of an electronic } \\
\text { communication network } \\
\text { and an accurate database } \\
\text { between governmental } \\
\text { agencies }\end{array}$ \\
\hline
\end{tabular}

*Correlation is significant at the 0.01 level (2-tailed)

It is clear from Table 10 that the value of Pearson's Correlation Coefficient, $r$, between a more effective electronic communication network and an accurate shared governmental agencies database to enable these entities to more effectively limit shadow economy activities is 0.542 and is statistically significant at the 0.01 level. Accordingly, it is concluded that there is a statistically significant positive correlation between a more effective electronic communication network and an accurate shared governmental agencies database to enable these entities to more effectively limit shadow economy activities. Therefore, this result supports the fifth hypothesis of the study since the more effective existence of an electronic communication network and an accurate database between governmental agencies, the higher possibility to limit the large volume of funds smuggled outside the Kingdom's borders either by foreigners or small business owners. The most prominent factors that contributed to this result are the following:

The communications revolution; The informal economy secures additional income to individuals who work in the government sector and own their private small businesses managed by foreigners sponsored by them or by their spouses or any of their relatives.

\subsection{Testing the Validity of the Sixth Hypothesis}

"There is a correlation between shadow economy, the decline of service quality of governmental agencies, the low standard of living and the devaluation of the national currency". 
Table 11. Display of the average score and arithmetic mean to the questionnaire related to the correlation between shadow economy, the decline of service quality of governmental agencies, the low standard of living and the devaluation of the national currency

\begin{tabular}{|c|c|c|c|c|c|c|c|}
\hline & $\begin{array}{l}\text { Strongly } \\
\text { Agree }\end{array}$ & Agree & Neutral & Disagree & $\begin{array}{l}\text { Strongly } \\
\text { disagree }\end{array}$ & $\begin{array}{l}\text { The } \\
\text { Mean }\end{array}$ & $\begin{array}{l}\text { Standard } \\
\text { deviation }\end{array}$ \\
\hline $\begin{array}{l}\text { The necessity to activate the } \\
\text { role of universities and } \\
\text { Chambers of Commerce to } \\
\text { acquaint small business owners } \\
\text { with the risks arising from the } \\
\text { spread of shadow economy } \\
\text { phenomenon. }\end{array}$ & 23.4 & 70.8 & 3.6 & 2.2 & 0.0 & 4.15 & 0.58 \\
\hline $\begin{array}{l}\text { The monetary policies of some } \\
\text { foreign countries have } \\
\text { contributed to accept cash } \\
\text { remittances from migrant } \\
\text { workers without careful } \\
\text { examination of funds' sources. }\end{array}$ & 36.5 & 58.4 & 3.6 & 1.5 & 0.0 & 4.3 & 0.61 \\
\hline $\begin{array}{l}\text { The large number of family } \\
\text { members forces the head of the } \\
\text { family to search for an } \\
\text { additional source of income and } \\
\text { evade income tax payment. }\end{array}$ & 34.3 & 59.9 & 3.6 & 1.5 & 0.7 & 4.26 & 0.67 \\
\hline $\begin{array}{l}\text { Concentration on illegal } \\
\text { businesses and transformation } \\
\text { of the society's culture from a } \\
\text { society based on trade to a } \\
\text { non-productive society which } \\
\text { consequently affects social } \\
\text { values. }\end{array}$ & 24.1 & 70.8 & 2.9 & 2.2 & 0.0 & 4.17 & 0.58 \\
\hline $\begin{array}{l}\text { The state may impose additional } \\
\text { taxes in case of the evasion of } \\
\text { imposed taxes; a case that } \\
\text { associates financial burdens } \\
\text { especially for newly founded } \\
\text { small businesses. }\end{array}$ & 26.3 & 66.4 & 4.4 & 2.9 & 0.0 & 4.16 & 0.63 \\
\hline \multicolumn{6}{|c|}{ The Weighted Average } & 4.21 & 0.61 \\
\hline
\end{tabular}

It is clear from the results of Table 11 that the questionnaire respondents for this section indicate that the shadow economy contributes, directly or indirectly, to a great extent to the decline of service quality of governmental agencies, the low standard of living and the devaluation of the national currency. This result is supported by the Weighted Average of 4.21 and a standard deviation of 0.61 . These results are mainly due to a combination of factors, the most prominent of which are:

- The monetary policies of some foreign countries have contributed to accept cash remittances from migrant workers without careful examination of funds' sources;

- The large number of family members forces the head of the family to search for an additional source of income and evade payment of income tax;

- Concentration on illegal businesses and transformation of the society's culture from a society based on trade to a non-productive society consequently affects social values. 
To investigate the existence of a correlation and a statistically significant relationship between the shadow economy and the decline of service quality of governmental agencies, the low standard of living and the devaluation of the national currency, Pearson's Correlation Coefficient, $r$, was used as shown in the Table below:

Table 12. The correlation between the shadow economy and the decline of service quality of governmental agencies, the low standard of living and the devaluation of the national currency

\section{Correlations}

\begin{tabular}{|c|c|c|c|}
\hline $\begin{array}{l}\text { The decline of service quality of } \\
\text { governmental agencies, the low standard of } \\
\text { living and the devaluation of the national } \\
\text { currency }\end{array}$ & $\begin{array}{c}\text { Shadow } \\
\text { Economy } \\
\text { Phenomenon }\end{array}$ & & \\
\hline $.362^{*}$ & 1 & Pearson Correlation & \\
\hline .000 & & Sig. (2-tailed) & $\begin{array}{l}\text { Shadow Economy } \\
\text { Phenomenon }\end{array}$ \\
\hline 137 & 137 & $\mathrm{~N}$ & \\
\hline 1 & $.362 *$ & Pearson Correlation & $\begin{array}{l}\text { The decline of service } \\
\text { quality of governmental }\end{array}$ \\
\hline 137 & & $\begin{array}{l}\text { Sig. (2-tanled) } \\
\mathrm{N}\end{array}$ & $\begin{array}{l}\text { agencies, the low standard } \\
\text { of living and the } \\
\text { devaluation of the national } \\
\text { currency }\end{array}$ \\
\hline
\end{tabular}

*Correlation is significant at the 0.01 level (2-tailed)

It is clear from Table 12 that the value of Pearson's Correlation Coefficient, $r$, between the decline of service quality of governmental agencies, the low standard of living and the devaluation of the national currency and the shadow economy phenomenon is 0.362 is statistically significant at the 0.01 level. Accordingly, we conclude that there is a statistically significant positive correlation between the decline of service quality of governmental agencies, the low standard of living and the devaluation of the national currency on one hand and the shadow economy activities on the other. We can conclude from the above that the shadow economy has a direct effect on the decline of government services, the low standard of living and the devaluation of the national currency. Due to the fact that transferred funds are invested in the foreigners' native countries, funds do not move in their natural business cycle in the national economy. Moreover, tax evasion has resulted in a low level of government services, consequently leading to a decline in the standard of living. Apparently, the primary shadow economy beneficiaries are foreigners who manage these types of businesses. Thus the researcher proposes to establish and implement scientific measures to impose taxes on all small business activities in the Kingdom in order for them to play their role in contributing to support the nation's educational, health and social services. The proposed system must take into account the type of business activity and the existence of an accurate accounting system that identifies sources of income and the annual revenues generated from each particular business activity.

\subsection{Testing the Validity of the Seventh Hypothesis}

"There is a direct correlation between the shadow economy and the criminal economy".

Table 13. Display of the average score and arithmetic mean to the questionnaire related to the correlation between the shadow economy and the criminal economy

\begin{tabular}{lccccccc}
\hline & $\begin{array}{c}\text { Strongly } \\
\text { Agree }\end{array}$ & Agree & Neutral & Disagree & $\begin{array}{c}\text { Strongly } \\
\text { disagree }\end{array}$ & $\begin{array}{c}\text { The } \\
\text { Mean }\end{array}$ & $\begin{array}{c}\text { Standard } \\
\text { deviation }\end{array}$ \\
\hline $\begin{array}{l}\text { The shadow economy contributes } \\
\text { to the failure to set up economic } \\
\text { policies and failure to identify } \\
\text { unemployment rates and } \\
\text { economic growth rates. }\end{array}$ & & & & & & & \\
\hline
\end{tabular}


The shadow economy contributes to the rise of drug trade.

27.7

$66.4 \quad 4.4$

1.5

0.0

4.20

0.58

The shadow economy contributes to behavioral changes in consumption and production.

29.2

62.8

5.8

2.2

0.0

4.19

0.64

The shadow economy contributes to behavioral changes among the youth and encourages them to commit embezzlement and illegal 32.8 $59.9 \quad 4.4$

2.9

0.0

4.23

0.66 acts to become wealthy.

The shadow economy contributes to the devaluation of local currency and increases the

61.3

4.4

2.2

0.0

4.23

0.63

demand for hard currency.

The shadow economy contributes to the preoccupation of all government agencies in combating tax evasion activities.

$\begin{array}{lllllll}36.5 & 56.2 & 4.4 & 2.9 & 0.0 & 4.26 & 0.68\end{array}$

\section{The Weighted Average}

It is clear from the results of Table 13 that the questionnaire respondents for this section indicate that the shadow economy contributes to a great extent to the existence of criminal economy. This result is supported by the Weighted Average of 4.21 and a standard deviation of 0.65 . The main aspects representing the shadow economy's sustenance of the criminal economy are the following:

- The shadow economy contributes to the preoccupation of all government agencies in combating tax evasion activities.

- The shadow economy contributes to behavioral changes among the youth and encourages them to commit embezzlement and illegal acts to become wealthy.

- The shadow economy contributes to the devaluation of local currency and increases the demand for hard currency.

- The shadow economy contributes to the rise of drug trade.

These results are supported by the Mean (4.26, 4.23, 4.23, and 4.20) consecutively. To investigate the existence of a correlation and a statistically significant relationship between the shadow economy and the criminal economy, Pearson's Correlation Coefficient, r, was used as shown in the Table below:

Table 14. The correlation between shadow economy and criminal economy

\section{Correlations}

\begin{tabular}{cclc}
\hline Criminal economy & Shadow Economy & & \\
\hline $.839 *$ & 1 & Pearson Correlation & \\
.000 & & Sig. (2-tailed) & Shadow \\
137 & 137 & $\mathrm{~N}$ & Economy \\
1 & $.839^{*}$ & Pearson Correlation & \\
& .000 & Sig. (2-tailed) & Criminal \\
137 & 137 & $\mathrm{~N}$ & economy \\
\hline
\end{tabular}

*Correlation is significant at the 0.01 level (2-tailed) 
It is clear from Table 14 that the value of Pearson's Correlation Coefficient, $r$, between the shadow economy and the criminal economy is 0.839 and is statistically significant at the 0.01 level. Accordingly, we conclude that there is a statistically significant positive correlation between the shadow economy and the criminal economy. Therefore, it can be concluded from the above that the shadow economy is an essential factor that has encouraged the emergence of criminal economy, thus necessitating the establishment of appropriate measures and remedies to positively succeed in the reduction of the shadow economy phenomenon.

\section{Conclusions of the Study}

Based on the field data analysis, the study has reached several conclusions including the following:

1. The study reveals that a positive correlation and a statistically significant relationship exist between the shadow economy and the performance efficiency of small businesses in the Saudi economy. The persuasive justification of this relationship can be contributed to the tax evasion of small business owners which has led to the growth of their profits, thus resulting in the expansion of these businesses and the increase of their volume.

2. The study demonstrates that a positive correlation exists between the narrow corporate culture of small business owners and the spread of shadow economy phenomenon. This gives rise to another emergent phenomenon namely, commercial concealment. Foreign workers engaged in small businesses are sponsored by Saudi citizens (under the sponsorship "kafala" system) who are keen to prolong the stay of those foreigners due to mutual interests. The negative effects of the spread of businesses conducted under the shadow economy do not contribute to the development of state services due to inherent tax evasion.

3. The study reveals that a positive correlation and a statistically significant relationship exist between the shadow economy and the tendency of semi-foreign owned small businesses to increase in frequency in the Saudi economy. The most prominent factors that contribute to this result are the following: The communications revolution; The informal economy secures additional income to individuals who work in the government sector and own their private small businesses managed by foreigners sponsored by them or by their spouses or relatives.

4. The study shows that there is a statistically significant correlation between an effective electronic communication network and accurate statistically significant and the monitoring of shadow economy activities. Therefore, the more effective the shared electronic information network is between national banks, the more effectively shadow economy activities can be monitored; which consequently lead to limit the increase of false small businesses semi-owned by foreigners under concealment by some citizens.

5. The study reveals that there is a statistically significant positive correlation between the existence of an effective electronic communication network and an accurate shared governmental agencies database in the reduction of shadow economy activities. Therefore, this result supports the fifth hypothesis of the study since the availability of a more effective electronic communication network and accurate governmental agencies database increases the potential for limiting and reducing the large volume of funds smuggled outside the Kingdom's borders either by foreigners or small business owners.

6. The study shows that the shadow economy has a direct effect on the decline of government services, the low standard of living and the devaluation of the national currency. Due to the fact that transferred funds are invested in the foreigners' native countries, funds do not move in their natural business cycle in the national economy. Moreover, tax evasion has resulted in a low level of government services consequently leading to a decline in the standard of living. Apparently, the shadow economy primary beneficiaries are foreigners who operate and manage these businesses.

7. There is a statistically significant positive correlation between the shadow economy and the criminal economy. Therefore, it can be concluded that the shadow economy is an essential factor that has encouraged the emergence of the criminal economy, thus necessitating the establishment of appropriate measures and remedies to positively succeed in the reduction of the shadow economy phenomenon.

8. The main aspects representing the shadow economy's sustenance of the criminal economy are the following:

- The shadow economy contributes to the preoccupation of all government agencies in combating tax evasion activities.

- The shadow economy contributes to behavioral changes among the youth and encourages them to commit embezzlement and illegal acts to become wealthy. 
- The shadow economy contributes to the devaluation of local currency and increases the demand for hard currency.

- The shadow economy contributes to the rise of drug trade.

\section{Recommendations}

- Monitoring the bank transfers of foreign workers and the necessity of opening a bank account for each worker, as workers should receive their payments via banks.

- Monitoring money smuggling through maritime customs because most workers in the Saudi Arabia come from Africa and are of a modest social level so some of them have never dealt with banks.

- Developing an accounting system for shops, especially small businesses, and the necessity of dealing through banks in all supply and procurement processes.

- Eradicating administrative complexities and enforcing the ruling that personal relationships that involve improper use of rank or position for personal gain are to be strictly avoided. In addition to strictly refraining from coercing people to resort to back doors or illegitimate means to complete their business transactions in order to prevent businessmen from having control over officials in governmental sectors and to fight against bribery and administrative corruption.

- Encouraging individuals to register their small businesses, facilitating the grant of work permits, refraining from bureaucracy, and Focusing on academic communication with universities.

- Spreading the culture of small businesses among young people and rejecting the idea of professional disadvantage and supporting them financially, legally and consultant as per Ghamri (2004).

- Monitoring central commercial districts and zones, regulating unregistered retail outlets and warehouses, conducting joint market monitoring visits through the Ministries of Interior, Finance and Trade, especially to public markets, and acting to develop the vocational education and training system for workers in such places.

- Taking into account that education matches the market needs regarding the vocational and professional skills.

- Raising awareness of joining associations, syndicates and unions and developing a database of all professions and employees of such associations.

- Developing programs and policies to monitor private sector wages, and providing social and economic security for elderly retired workers which should commensurate with the standard of living and purchasing power.

- Taking advantage of visual media to educate Saudis about the seriousness of shadow economy and its impact on the national economy and youth.

- Establishing an effective tax system, fighting the unemployment stigma, re-distributing income and making use of the economic climate by encouraging individuals to set up small businesses, especially during economic recessions in which individuals' incomes decline.

- Monitoring work visas and making sure workers bound to only the professions or crafts assigned to them or the ones they came to the country for.

- Fighting against illegal actions of all kinds and identifying the nationalities of workers that are involved in such actions.

- Developing Arabic legislation for all Arab countries to fight money laundering as shadow economy outlines the aspects of cooperation and coordination between the financial, banking, legislative institutions and the security agencies in the Arab countries as stated by Mustafa \& Muhammad (2008).

- Encouraging future studies that are related to shadow economy, money laundering, concealment of trade, foreign labor and Saudization that all contribute to the exhaustion of Saudi economy.

\section{References}

Abd, Muhammad Fadheel. (1999, May). Corruption and its Impact in the Arab World. Journal of Arab Future, (243). Abdul-Salam, Safwat. (2002). Secret Economy (1st ed.). Dar Al-Nahda Al-Arabia Publishing House, Cairo, Egypt.

Agila, M., Bin Nawi, M. \& Ghazeel, M. (2007). Requirements of Informal Economy in Algeria: Concepts and Foundations. University of Moulay, Saida, Algeria, P. 12.

Al-Julaydan, Saud. (2012). Hidden or Unregulated Economy. Al-Aiqtisad (Saudi) Newspaper (1st ed.). (6792). 
Al-Khuraisha, Amjad Saoud. (2006). Money Laundering Crime. Culture House (1 ${ }^{\text {st }}$ ed.), Amman, Jordan. P. 10.

Al-Mutairi, Laila. (2014). The Impact of Hidden Economy on Economic Growth in KSA. Kingdom of Saudi Arabia. P. 9.

Al-Sakka, Muhammad. (2012). Flight of Capital. Al-Aiqtisadia Journal, Electronic Issue (6868).

Al-Suhaimi, Abdulmajid. (2011). Commercial Concealment. Islamic University, College of Sharia'ah and Regulations, Madinah, Saudi Arabia, p. 5.

Bo-Dalal Ali. (2008). The Problem of Hidden Economy in Algeria: Causes and Solutions. Human Sciences Journal, 37(15). Faculty of Economic Sciences, Management and Commerce sciences, University of Tlemcen, Algeria.

Boumediene, \& Gharbi, Salah Al-Din. (2015). The Impact of Small Businesses on Informal Economy. Faculty of Economic Science, University of Tlemcen, Algeria, P. 5.

Chamber of Commerce. (2010). Commercial Concealment. Eastern Province, Saudi Arabia May, P. 2.

Economic and Social National Council pamphlets, (2004). Illusions and Realities. Regular plenary session, Informal sector, 24th of June.

Ghamri, Nayef. (2004). Small businesses (1st ed.). Dar Hafez Publishing House, Jeddah, Saudi Arabia.

Ghamri, S. Nayef. (2009). Money Laundering. Faculty of Economics and Administration, King Abdulaziz University, Jeddah, Saudi Arabia.

Gutmann, P. (1977). The Subterranean Economy. Financial Analysts Journal, 34(1).

Hayan, Salman. (2006). Shadow and Hidden Economy. Administration of the Syrian Economic Sciences Association, Faculty of Economics and Administration.

Jumaah, Fahad. (2014, July). Shadow Economy Combat Authority. Al-Riyadh (Saudi) Newspaper (1st ed.), (16815).

Marefa encyclopedia website. Retrieved $17^{\text {th }}$ July 2015, from http://www.marefa.org/index.php

Mustafa, Manahel, \& Muhammad, Iftekhar. (2008). The Role of Banks to Cope with Financial Fraud and Money Laundering. Baghdad, Iraq. P. 17.

Nashed, Suzie Adel. (2005). Human Trafficking. New University Publishing House, Alexandria, Egypt.

Owais, Ibrahim. (1995, November). The Reality of Hidden Economy. Islamic Finance Journal, 175(15).

Saleh, Muhammad Ahmad. (2011, May). Money Laundering Crime. Al-Riyadh (Saudi) Newspaper (1st ed.), (15673).

Sarayrah, Mansour. (2005). The Problem of the Hidden Economy and the Role of Banks in Combating it. The School of Law, Mu'tah University, Jordan. P. 13-14.7

The International Labor Office report No. 15 for Labor Statisticians. (1993).

Thunayyan, Fahd. (2014, October). World Bank: The Size of Shadow Economy in the Kingdom of Saudi Arabia Rises to 549 Billion Riyals. Al-Riyadh (Saudi) Newspaper ( $1^{\text {st }}$ ed.), (16926). 